\title{
Nilai Budaya dalam Lagu Banjar: Pernikahan, Mata Pencaharian, dan Permainan Tradisional
}

\author{
Akhmad Humaidi \\ STKIP PGRI Banjarmasin \\ e-mail: amat_humai@yahoo.co.id
}

\begin{abstract}
Abstrak
Lagu memiliki fungsi utama sebagai media hiburan bagi masyarakat. Setiap daerah memiliki gaya bahasanya tersendiri dalam menciptakan lagu daerah. Penelitian mengenai lirik lagu bertujuan untuk mengungkapkan berbagai aspek budaya dalam kehidupan masyarakatnya. Penelitian ini mengkaji nilai budaya Banjar dari kata-kata yang terdapat pada lagu Banjar ciptaan Anang Ardiansyah, yaitu pernikahan, mata pencaharian, dan permainan. Lagu Anang Ardiansyah yang mencerminkan pernikahan menggambarkan tentang jodoh dan pernak pernik pernikahan. Jodoh dalam pandangan masyarakat Banjar sudah ditetapkan oleh Sang Maha Pencipta sehingga para pemuda yang belum menikah tidak perlu terlalu khawatir. Mereka dinasehati melalui lagu-lagu itu untuk terus berusaha. Pernak perik pernikahan yang ditonjolkan ialah pemakaian bunga-bunga khusus yang digunakan oleh pengantin. Nilai budaya mata pencaharian yang tercermin dalam penggunaan kata-kata pada lagu daerah Banjar ialah kegigihan masyarakat ketika berdagang. Mereka pergi merantau ke berbagai tempat untuk memasarkan barang dagangan mereka. Permainan yang tercermin dalam pilihan kata ialah tentang balogo. Permainan tradisional ini ditampilkan dengan kata-kata yang jenaka sesuai dengan fungsinya sebagai hiburan. Lagu dapat dijadikan sebagai sarana untuk melestarikan nilai budaya untuk kepentingan generasi yang akan datang. Melalui teks dalam lagu daerah, mereka akan tetap mengetahui berbagai unsur kebudayaan nenek moyangnya.
\end{abstract}

Kata Kunci: Banjar, lagu, nilai budaya,

\section{PENDAHULUAN}

Dewasa ini, lagu daerah mengalami persaingan yang cukup keras dengan lagu modern. Kenyataan ini terjadi akibat perkembangan dunia yang mengarah pada globalisasi. Di satu pihak. Situasi ini membuat teknologi berkembang semakin pesat. Informasi menjadi lebih mudah diakses. Namun, di pihak yang lain, globalisasi secara perlahan-lahan membuat kebudayaan lokal semakin pudar. Lagu daerah sebagai salah satu cerminan dari kebudayaan lokal semakin lama semakin tersingkir oleh modernitas. Kekhawatiran ini ditunjukkan oleh Setiawan dalam penelitiannya. Setiawan (2012) menunjukkan bagaimana lagu daerah Lirilir khas daerah Jawa Tengah mengalami kepunahan karena lagu daerah ini sudah jarang sekali diperdengarkan kecuali pada acara-acara tertentu. Masyarakat dan pemerintah seharusnya berusaha untuk melestarikan dan mengembangkan lagu daerah yang ada di Indonesia agar tidak lenyap dan menjaganya agar lebih dicintai daripada lagu-lagu modern yang lebih mengarah pada sekularisme.

Salah satu penyebab kurangnya apresiasi masyarakat terhadap lagu daerah ialah keterbatasan pemahaman masyarakat tentang kata-kata yang terdapat dalam 
lagu daerah. Keadaan ini membuat masyarakat yang menjadi penikmat lagu tidak memahami pesan atau nilai yang terkandung di dalamnya. Hal ini yang terjadi pada lagu daerah di Madura. Azhar (2009) mengambil simpulan dalam penelitiannya bahwa masyarakat Madura sendiri kurang menghargai syair-syair tersebut dan hanya menempatkannya sebagai karya budaya yang tidak memiliki peran signifikan dalam membangun masyarakat Madura. Padahal, ketika ditelaah lagu-lagu ini sebenarnya dapat dijadikan sebagai media untuk mereprsentasikan jati diri masyarakat. Hal itu tercermin melalui simbol-simbol sosial yang menjadi acuan dan pegangan hidup masyarakat.

Dalam teori realivitas linguistik, lagu dan budaya bersifat reflektif dan generatif satu sama lain. Bahasa dan musik dalam lagu merupakan alat komunikatif dan mempengaruhi satu sama lain (Mannion, C. M., \& Sanatullova, 2012). Pemahaman mengenai hubungan musik dan kata dengan budaya dalam lagu akan menjelaskan posisi masyarakat. Pengetahuan ini tidak hanya menyediakan budaya individual, pengetahuan ini juga menyediakan petunjuk keberadaan kemanusiaan di dunia saat ini.

Pascale (2013) menjelaskan bahwa lagu memiliki potensi untuk menyatukan dan menguatkan suatu komunitas. Lagu memegang peran yang penting dalam sebuah budaya. Bahkan, masyarakat yang mendengarkannya terkadang akan menerima pesan di dalamnya tanpa mempertanyakannya. Pemerintah melalui kurikulum sekolah perlu memastikan lagu dapat menjadi bagian yang menyatu dalam pendidikan anak secara berkelanjutan. Proses pendidikan dengan menggunakan lagu merupakan proses inkulturasi (Otchere, 2015). Pengembangan mental dan karakter anak akan menjadi jauh lebih menarik dengan lagu.

Hal ini dimanfaatkan oleh negara-negara kolonial di masa lalu untuk menyebarkan budaya mereka kepada negara jajahannya. Akulturasi musik dapat diobservasi pada sebagian besar negara-negara yang pernah dijajah. Misalnya, lagu militer merupakan tugas umum anak-anak sekolah di negara tertentu. Berdasarkan penelitian yang dilakukan oleh Kim (2014), anak-anak Korea lebih mudah mengingat lagu-lagu semacam ini karena selalu dinyanyikan di acara-acara resmi. Mereka hanya menghabiskan dua tahun di sekolah, tetapi mereka masih mengingatnya dan menyanyikannya hingga dewasa. Anak-anak merekam lagulagu itu dan menyimpannya dengan sangat kuat selama bertahun-tahun selanjutnya. Hal menunjukkan bahwa lagu memiliki pengaruh yang sangat besar terhadap para pendengarnya jika diputar atau dinyanyikan secara terus-menerus.

Pemilihan lagu yang kurang tepat akan berdampak negatif bagi para pendengar khususnya anak-anak. Hal inilah yang terjadi di Ghana dan Korea Selatan oleh negara kolonial yang menduduki wilayah ini. Kurikulum masa kolonial yang menyelipkan kebiasaan menyanyikan lagu asal mereka di negeri jajahannya menyebabkan budaya asli negara itu tergeser. Oleh sebab itu, lagu daerah perlu mendapatkan perhatian yang besar sebagai salah satu sarana untuk memperkenalkan budaya lokal kepada generasi muda.

Nilai budaya merupakan konsep hidup di dalam alam pikiran sebagian besar warga masyarakat mengenai hal-hal yang dianggap sangat bernilai, berharga, dan penting di dalam kehidupan sehingga dapat berfungsi sebagai pedoman yang memberikan arah dan orientasi kepada kehidupan warga masyarakat. Koentjaraningrat (1990) berbendapat bahwa suatu nilai bersifat 
sangat umum. Sifatnya yang umum, luas dan konkret itu, membuat nilai dalam suatu kebudayaan berada dalam daerah emosional di alam jiwa para individu yang menjadi warga. Dengan demikian, nilai dapat dijadikan panutan, pedoman, serta penggerak terhadap tindakan, ucapan, perbuatan, dan perilaku manusia sebagai makhluk pribadi, sosial, budaya, dan hamba dari pencipta-Nya.

Dengan demikian, kajian untuk menelaah lagu daerah sangat penting untuk dilakukan. Kajian melalui teks lagu akan membantu masyarakat untuk memahami nilai-nilai budaya yang terkandung di dalamnya. Sebagai promosi budaya, lagu merupakan sarana yang sangat efektif tidak hanya anak-anak, tetapi juga orang dewasa sekalipun. Lagu yang diputar secara terus-menerus akan membuat para pendengarnya mengingat pesan-pesan lagu itu.

Masyarakat Banjar memiliki sejumlah penulis lagu daerah yang populer. Lagu-lagu yang mereka ciptakan mengandung nilai budaya yang kental. Lagu Banjar adalah lagu- lagu berbahasa Banjar. LaguBanjar pada umumnya berisikan kebiasaan orang Banjar dalam keseharian. Banyak sekali pencipta maupun penyanyi lagu Banjar yang ada di Kalimantan Selatan, antara lain, A. Hamid, A. Thamrin, Agit Kursani, Hamka, Mas'ud dan masih banyak lagi yang lainnya. Namun, pencipta lagu Banjar yang paling berpengaruh adalah H. Anang Ardiansyah. Beliau penulis lagu Banjar yang sangat produktif, lagu- lagu ciptaannya telah mencapai 103 judul. Dengan banyaknya lagu yang diciptakan, beliau disebut sebagai maestro lagu- lagu Banjar. Melaluilirik- liriklagunya, $\mathrm{H}$. Anang Ardiyansyah berusaha memperkenalkan bahasa Banjar dan kebudayaan yang terkandung di dalamnya.

Penelitian ini mencoba menggali nilai-nilai budaya Banjar yang terkandung dalam lirik-lirik lagu ciptaan Anang Ardiansyah tersebut. Kajian ini bertujuan agar masyarakat mampu memahami nilai budaya yang terkandung dalam lirik lagu Banjar dengan lebih baik sehingga apresiasi pendengar menjadi lebih tinggi. Dengan demikian, budaya Banjar dapat lebih kokoh bertahan dari gempuran budaya modern yang terjadi saat ini.

\section{METODE}

Metode yang digunakan untuk menganalisis data adalah metode deskriptif. Metode ini dipilih karena tujuan penelitian ini berusaha menggambarkan isi dari lagu Banjar karya H. Anang Ardiansyah. Sumber data utama penelitian ini adalah lagu Banjar karya $\mathrm{H}$. Anang Ardiansyah yang diperoleh dari rekaman berupa CD. Data awal berbentuk audio visual. Selanjutnya, transkripsi dilakukan untuk mengubah data menjadi bentuk tulisan demi mempermudah analisis data. Keuntungan yang diperoleh melalui media teks seperti ini ialah kemudahan akses. Beragam bentuk media membuat teks-teks mudah untuk dilihat dan dianalisis. Mempelajari teks dapat memperbaiki pemahaman kita mengenai kehidupan kultural tentang makna berbagai hal karena makna itu sendiri merupakan salah satu aspek paling penting dalam penggunaan media (Stokes, 2007).

Analisis nilai budaya pada objek penelitian dilakukan dalam lima tahap, yaitu: (1) analisis domain prinsip dengan membaca data secara berulang-ulang sehingga diperoleh data yang benar-benar mengandung nilai; (2) analisis taksonomi, yakni mengidentifikasi dan mengklasifikasi data secara utuh menurut setiap kelompok nilai budaya; (3) analisis komponensial, yaitu penyajian, penafsiran data dan penganalisisan semua data yang berkenaan dengan nilai; (4) 
penarikan kesimpulan; dan (5) verifikasi dengan informan dan pakar untuk menguji kebenaran interpretasi dan kecocokannya dengan data.

\section{HASIL DAN PEMBAHASAN}

Secara langsung atau tidak langsung, Anang Ardiansyah menyisipkan kebudayaan-kebudayaan yang dimiliki masyarakat Banjar. Wujud kebudayaan yang muncul ada tiga bentuk, yaitu gagasan atau ide, pola aktivitas masyarakat, dan karya seni. Banyak lagu-lagu yang diciptakan menggambarkan bagaimana pola pikir masyarakat. Pola pikir ini biasanya ditampilkan dalam bentuk penilaian terhadap baik dan buruk suatu tindakan. Pola aktivitas masyarakat tercermin dalam bentuk ritual masyarakat dalam suatu perayaan, seperti pernikahan.

Penelitian ini menemukan tiga nilai budaya Banjar dalam lagu-lagu yang diciptakan oleh Anang Ardiansyah. Berdasarkan data-data yang dikumpulkan nilai budaya yang dimaksud, yaitu pernikahan, mata pencaharian, dan permainan. Pembahasannya adalah sebagai berikut.

\section{Pernikahan}

Pernikahan merupakan salah satu kebudayaan Banjar yang unik. Proses pernikahan masyarakat Banjar memiliki tahap-tahap khusus. Anang Ardiansyah secara singkat menggambarkan hal ini dalam lagu ciptaannya. Ada tiga lagu yang dapat dikaji untuk menggambarkan bagaimana pandangan masyarakat Banjar mengenai pernikahan. Lagu pertama berjudul Ampat Lima. Lagu ini mencerminkan pandangan masyarakat mengenai tahap yang dilalui oleh para pemuda dan pemudi sebelum menikah. Lagu kedua berjudul Kambang Goyang. Lagu ini mengilustrasikan berbagai pernak pernik yang terdapat dalam sebuah proses pernikahan masyarakat Banjar. Lagu lain yang menyiratkan persoalan ini ialah Kambang Barenteng.

\section{Jodoh dalam Pandangan Masyarakat Banjar}

Lagu Ampat Lima merupakan lagu yang sangat populer. Lagu ini sangat digemari oleh masyarakat Banjar dan sering diputar di berbagai tempat. Selama bertahun-tahun lagu ini terus bertahan dan diputar dalam berbagai kesempatan. Lagu ini menjelaskan sekilas tentang pandangan masyarakat mengenai persoalan jodoh. Kutipan lagu yang mencerminkan tentang persoalan ini terlihat pada teks berikut ini.

Ampat si ampat lima kaka ay
'ku tanding sudah
kada manyaman, kada manyaman,
nang baju habang
Banyak urang nang maantar tapih
sarung)
salambar-lambar kada bakain
Banyak sudah urang nang mamilih
Juduhnya kada ka lain

Ampat si ampat lima kaka ay ku tanding sudah

kada manyaman, kada manyaman, nang baju habang

Banyak urang nang maantar tapih sarung)

Banyak sudah urang nang mamilih Juduhnya kada ka lain
(Empat si empat lima Ka)

(Sudah aku tanding)

(tidak cocok, tidak cocok)

(yang berpakaian merah)

(Banyak orang yang mengantar

(selembarpun tidak ada kain)

(sudah banyak orang yang memilih)

(Jodohnya tidak ke lain)

(Anang Ardiansyah, Ampat Lima)

Secara sekilas lagu ini menceritakan tentang salah satu tahap dalam pernikahan masyarakat Banjar. Proses pernikahan dalam masyarakat Banjar sebenarnya cukup panjang. Sebelum menikah, ada tahap-tahap perkenalan terlebih 
dahulu, yaitu basasuluh, badatang, maantar patalian, dan seterusnya. Dalam lagu ini, Anang Ardiansyah menonjolkan tahap maantar patalian. Pangiring atau lebih sering dinamakan patalian ini sering berupa bahan pakaian dan alat kosmetik (Daud, 1997).

Lagu ini secara tidak langsung menceritakan bahwa ada lima orang yang telah dibanding-bandingkan oleh penulis. Namun, penulis mengatakan bahwa semuanya tidak ada yang cocok. Dalam kutipan lagu ini, Anang Ardiansyah mengatakan "Banyak urang nang maantar tapih" yang berarti banyak orang yang mengantar tapih atau sarung. Kata tapih di sini melambangkan seperangkat barang yang digunakan untuk melamar pada tahap maantar patalian. Meskipun singkat, lirik ini mengandung nilai budaya yang begitu dalam yang menceritakan tentang tahap-tahap pernikahan pada masyarakat Banjar.

Pada lirik terakhir, Anang Ardiansyah mengatakan bahwa jodoh seseorang seringkali tidak terduga dan mereka tidak akan pergi ke mana-mana. Maksudnya ialah jodoh yang sampai pada tahap pernikahan seringkali bukan orang yang jauh, tetapi orang dekat dengan perempuan itu sendiri, seperti tetangga, teman, kerabat, dan sebagainya. Pandangan ini juga merupakan cerminan dari pola pikir masyarakat Banjar. Mereka meyakini bahwa setiap manusia telah memiliki jodoh masing-masing. Oleh sebab itu, laki-laki maupun perempuan tidak perlu khawatir tentang hal ini. Namun, usaha harus terus dilakukan dan tetap menyandarkan hasilnya pada Tuhan. Pola berpikir ini berangkat dari ajaran agama Islam yang merupakan sumber yang paling dominan bagi masyarakat Banjar.

\section{Pernak Pernik Pernikahan}

Perhiasan pengantin mendapat porsi yang cukup besar dalam lagu ciptaan Anang Ardiansyah. Perhiasan pengantin menjadi nilai budaya yang terlihat secara jelas karena bentuknya merupakan benda konkret bukan gagasan yang bersifat abstrak. Nilai kebudayaan ini dapat diamati pada kutipan berikut ini.

Aaa aaa aaa ooo ooo
Pangantinnya sudah batimung
batimung)
Amas murni pakaian putri
Kambang goyang di ujung galung
galung)

Aaа aаa aaa ooo ooo

Pangantinnya sudah batimung

batimung)

Amas murni pakaian putri

Kambang
galung

Lagu ini berjudul Kambang Goyang yang merupakan penyebutan salah satu perhiasan yang digunakan oleh pengantin perempuan ketika melangsungkan pernikahan. Perhiasan yang merupakan bagian dari tata busana selain berfungsi untuk memperindah penampilan, juga memiliki fungsi lain. Secara sosial budaya tata busana berkaitan dengan soal kepantasan, kesopanan, dan kepatutan dalam situasi tertentu (Hoed, 2011). Perhiasan ini dipakai di rambut pengantin perempuan yang terdiri dari bunga-bunga yang beranekaragam jenisnya, seperti melati.

Lagu ini juga sarat nilai-nilai budaya Banjar dalam bentuk pola aktivitas masyarakat ketika suatu pernikahan sedang berlangsung. Bentuk aktivitas yang ditampilkan dalam lagu ini ialah kebiasaan batimung. Biasanya sebelum pengantin memasuki bagian resepsi pernikahan, mereka diharuskan 
membersihkan diri agar lebih segar dan wangi. Masyarakat Banjar memiliki cara yang unik untuk mewujudkan hal ini, yaitu dengan cara batimung. Orang yang batimung akan dimasukkan dalam sebuah pembungkus yang terbuat dari anyaman purun. Setelah itu, di bagian bawahnya diletakkan air panas yang merupakan hasil dari rebusan rempah-rempah yang menghasilkan bau yang wangi. Hasil uap dari air akan membasahi calon pengantin sehingga badannya lebih wangi. Mereka diharuskan berada dalam pembungkus selama 20 hingga 30 menit. Proses inilah yang disebut batimung dalam masyarakat Banjar.

Selain pola aktivitas, Anang Ardiansyah juga memasukkan benda atau artefak yang dapat diamati secara langsung. Sesuai dengan judul lagu, bentuk kebudayaan yang dimaksud ialah kembang goyang. Perhiasan yang digunakan oleh pengantin ini merupakan hiasan berumpun sebanyak 11-13 kuntum. Bungabunga ini terdiri dari mawar dan melati yang bervariasi warnannya. Semua itu merupakan simbol yang dimaksudkan agar kedua mempelai terlihat menarik. Hal ini juga menjadi penanda identitas kebudayaan Banjar.

Selain itu, lagu ini mencerminkan secara lebih rinci tentang kepercayaan masyarakat Banjar tentang cara pemakaian perhiasan ini. Bunga yang merupakan perhiasan pengantin yang mendapat perhatian tersendiri. Hal ini terlihat pada kutipan berikut ini.

Suri kambang kambang malati

Pakaiakan di malam Arba

Kambang goyang di ujung galung

Pangantinnya sudah batimung
(Bunga melati)

(gunakan malam Rabu)

(Kambang goyang di ujung galung)

(Pangantinnya sudah batimung)

(Anang Ardiansyah, Kambang Goyang)

Nilai budaya perhiasan pengantin dalam kutipan ini terlihat pada teks yang berbunyi "Suri kambang kambang malati, pakaiakan di malam Arba" yang berarti bunga melati, gunakan di malam Rabu". Bunga melati yang dimaksud merupakan bagian dari perhiasan pengantin ketika melangsungkan pernikahan. Dalam kebudayaan Banjar terdapat istilah bahitungan, yaitu perhitungan untuk menentukan waktu, hari dan jam sial dan beruntungnya seseorang. Perhitungan diharapkan dapat menghindarkan seseorang dari kesialan atau kegagalan. Masuknya Islam dalam masyarakat Banjar membuat budaya ini menyesuaikan diri. Hari-hari tertentu dan bulan tertentu dianggap mempunyai nilai keramat. Hari Senin, Kamis dan Jum'at dianggap hari yang sangat keramat. Bulan Safar dianggap bulan yang "panas", yaitu masa ketika tindak kekerasan sering terjadi. Oleh sebab itu, pada bulan itu masyarakat Banjar menganggap tidak baik memulai usaha. Bulan Rajab dianggap sangat baik untuk melangsungkan perkawinan. Masyarakat Banjar telah membeda-bedakannya, bahkan pada tingkatan hari. Mereka menganggap hari tertentu merupakan masa ketika keberuntungan seseorang terjadi dan hari yang lain malapetaka dan peristiwa-peristiwa buruk yang akan terjadi. Malam Rabu merupakan salah satu hari yang diyakini oleh masyarakat Banjar sebagai hari yang baik untuk memakaikan kembang goyang pada pengantin perempuan. Nilai budaya ini yang ditampilkan oleh Anang Ardiansyah dalam lagu tersebut.

Perhiasan lain yang dapat muncul dalam proses pernikahan dapat diamati pada lagu berjudul Kambang Barenteng yang secara harfiah berarti rangkaian 
bunga. Kutipan lagu yang menyinggung sekilas tentang pernikahan dapat diamati pada teks berikut ini.
Jukung dua janganlah baalih
Balarut banyu sampai kasini
(Perahu dua jangan berpindah)
Kambang Barenteng pangikat kasih
Kasih sampai ka mati
(mengikuti arus sampai ke sini)
(Rangkaian bunga pengikat kasih)
(Kasih sampai mati)

(Anang Ardiansyah, Kambang Barenteng)

Lirik dalam lagu ini menjelaskan tentang salah satu benda yang menjadi lambang pernikahan, yaitu Kambang Barenteng. Kembang Barenteng adalah rangkaian bunga khas Kalimantan Selatan. Rangkaian bunga-bunga ini biasanya terdiri dari mawar, melati, cempaka, kenanga, kembang kuning, dan bunga kertas. Biasanya benda ini dipakai untuk keperluan ritual keagamaan, kematian, pernikahan hingga menyambut pejabat penting. Dalam lagu Anang Ardiansyah ini, kambang barenteng ini juga digunakan dalam pernikahan. Benda ini dijadikan lambang ikatan pernikahan.

Bentuk pernikahan yang juga menarik untuk ditelaah ialah pernikahan di lingkungan kerajaan. Lagu yang mendeskripsikan hal ini terdapat pada lagu berjudul Kambang Goyang. Tradisi yang dimaksud terlihat pada kutipan berikut ini.

$\begin{array}{ll}\text { Waktu raja duduk basanding } & \text { (Ketika raja duduk bersanding) } \\ \text { Kambang goyang di ujung galung } & \text { (Kembang goyang di ujung galung) } \\ \text { Amas murni pakaian putri } & \text { (Emas murni pakaian putri) } \\ \text { Adat kawin dalam istana } & \text { (Adat pernikahan dalam istana) } \\ & \text { (Anang Ardiansyah, Kambang Goyang) }\end{array}$

Sebagaimana sebelumnya, lagu ini masih menceritakan tentang pola masyarakat Banjar ketika melangsungkan pernikahan. Meskipun demikian, pada lirik ini, Anang Ardiansyah lebih memfokuskan pada tradisi pernikahan di lingkungan kesultanan Banjar. Hal ini terlihat pada kutipan yang berbunyi "Adat kawin dalam istana". Lirik ini menggambarkan adat pernikahan yang hanya terjadi di lingkungan kesultanan, yaitu duduk bersanding, penggunaan kembang goyang dan perhiasan berupa emas murni.

Saat ini adat kebiasaan itu tidak terbatas di lingkungan kesultanan Banjar saja. Kebiasaan ini telah menyatu dengan masyarakat Banjar di semua kalangan. Hal yang membedakan tinggal kemeriahan dan kemegahan acara. Bagi masyarakat biasa, kemeriahannya lebih kurang daripada pernikahan dalam keluarga yang ada di wilayah kesultanan. Selain itu, ada juga tradisi-tradisi khusus yang sedikit berbeda. Rincian ini dipaparkan lebih lanjut pada lirik lagu selanjutnya. Hal ini terlihat pada kutipan berikut ini.

Allahummasyalli ala Muhammad
Allahummasyali alaih
Uraiakan mayang nang sakti
Umpatakan balarut banyu
Adat raja bamandi-mandi

Allahummasyalli ala Muhammad

Allahummasyali alaih

Uraiakan mayang nang sakti

Adat raja bamandi-mandi
(Allahummasyalli ala Muhammad)

(Allahummasyali alaih)

(Sebarkan mayang yang sakti)

(Ikutsertakan air mengalir)

(Adat raja bamandi-mandi) 
(Anang Ardiansyah, Kambang Goyang)

Teks ini menggambarkan sekilas tentang tradisi bamandi-mandi. Sebelum acara perkawinan adat Banjar dilaksanakan ada satu adat yang sering dilakukan oleh calon pengantin, yaitu bapapai atau badudus. Bapapai atau badudus, memiliki fungsi yang sama, tetapi berbeda pada penempatannya. Badudus adalah istilah memandikan calon pengantin yang dilaksanakan oleh keluarga kerajaan atau keturunan bangsawan, sedangkan bapapai adalah istilah mandi-mandi yang dipakai oleh orang Banjar pada umumnya. Kata "papai" berarti "percik", dalam praktiknya bapapai seperti memercikkan air memakai mayang pinang kepada calon mempelai yang sedang dimandikan. Dalam teks ini, bamandi-mandi yang dimaksud ialah badudus karena konteks cerita pada lirik lagu ini menyangkut tradisi pernikahan pada keluarga sultan Banjar.

Pengucapan di lirik pertama dan kedua menggunakan bahasa Arab. Makna dari kedua lirik ini ialah salawat atau doa yang ditujukan kepada Nabi Muhammad saw. Meskipun tradisi Hindu masih terlihat serpihannya, Islam memiliki pengaruh yang lebih dominan bagi masyarakat Banjar. Melalui proses adaptasi, akulturasi, dan asimilasi tradisi Banjar membentuk tahap-tahap yang saat ini telah menjadi kebiasaan masyarakat.

Masyarakat Banjar meyakini pernikahan merupakan ikatan suci sepasang laki-laki dan perempuan. Keduanya harus menjaga hubungan ini dari berbagai permasalahan kehidupan. Hal ini sangat penting karena banyak pihak yang terlibat di dalamnya ketika mereka telah resmi berkeluarga. Oleh sebab itu, hubungan ini harus dipertahankan dengan sebaik-baiknya. Hal ini terlihat pada kutipan yang berbunyi "Rangkaian bunga pengikat kasih, Kasih sampai mati".

\section{Mata Pencaharian}

Mata pencaharian merupakan salah satu unsur kebudayaan yang selalu ada di masyarakat manapun. Masyarakat memiliki mata pencaharian yang bermacammacam tergantung dari kondisi masyarakat dan alamnya. Masyarakat Banjar umumnya tinggal di wilayah pinggir sungai. Hal ini sangat mempengaruhi cara mereka untuk mencari mata pencaharian. Sungai menjadi tempat utama untuk mencari nafkah. Pekerjaan yang sering mereka lakukan di wilayah ini ialah perdagangan. Barang yang diperjualbelikan sangat bermacam-macam, seperti barang kebutuhan pokok, buah-buahan, hasil alam, dan sebagainya. Proses jual beli ini dilakukan dengan memanfaatkan aliran sungai sehingga perahu menjadi alat transportasi yang sangat penting. Beberapa wilayah di Banjarmasin yang masih memanfaatkan sungai untuk melakukan jual beli, yaitu di wilayah Lok Baintan dan Kuin. Pasar ini biasanya hanya ada di waktu pagi hari. Selain waktu tersebut, aktivitas jual beli sangat jarang terjadi di sekitar sungai.

Anang Ardiansyah menggambarkan sekilas mengenai aktivitas masyarakat Banjar dalam mencari nafkah dengan memanfaatkan sungai. Hal ini terlihat pada lagu berjudul Puhun Rambai yang berarti pohon Rambai. Pohon rambai adalah sejenis pohon yang menghasilkan buah-buahan yang tumbuh liar atau setengah liar di kebun-kebun. Di Indonesia, pohon ini biasanya tumbuh di wilayah Sumatera dan Kalimantan. Kutipan lagu ini yang menggambarkan mata pencaharian masyarakat Banjar adalah sebagai berikut. 
Matan rantauan ka rantauan

perantauan)

Bajukung bajual pancarakinan pancarakinan)

Kada kada tarasa hari ka lawan bulan
(Sejak dari perantauan ke

(Pakai perahu berjualan

(Tidak terasa hari dan bulan)

(Anang Ardiansyah, Puhun Rambai)

Lagu ini secara keseluruhan menjelaskan tentang berbagai aktivitas yang dilakukan oleh masyarakat Banjar di sekitar sungai. Anang Ardiansyah menggambarkan pohon di lagunya tumbuh di pinggir sungai. Dia mempersonifikasikan pohon ini sebagai saksi yang mengamati aktivitas mayarakat. Aktivitas yang dimaksud ialah makan bersama, salat subuh dan magrib berjamaah, serta jual beli masyarakat.

Sebagai salah satu mata pencaharian masyarakat Banjar yang utama, perdagangan digambarkan dalam lirik lagu ini. Hal ini terlihat pada lirik yang berbunyi "Matan rantauan ka rantauan, bajukung bajual pancarakinan." Lirik ini berarti sejak dari perantauan yang satu ke perantauan yang lain, dengan perahu menjual pancarakinan. Kata pancarakinan bermakna rampah-rempah yang bisanya digunakan untuk memasak. Lirik ini menjelaskan bagaimana masyarakat Banjar berdagang. Mereka melewati sungai dengan menggunakan perahu yang disebut jukung untuk membawa barang dagangannya. Barang dagangannya dalam lirik ini ialah rempah-rempah dapur. Sebenarnya, masih banyak barang dagangan yang lain, seperti buah-buahan, sayuran, kue, makanan, perlengkapan rumah tangga, dan sebagainya.

Selain itu, Anang Ardiansyah juga menggambarkan bagaimana kegigihan masyarakat Banjar dalam berdagang. Dalam liriknya, digambarkan bahwa mereka tidak hanya berjualan di sebuah tempat, tetapi juga di banyak tempat. Selain itu, waktu yang digunakan untuk menjual barang dagangannya bisa mencapai waktu yang lama. Di lagu ini, Anang Ardiansyah menyebutkan hingga hitungan bulan. Kegigihan dalam berdagang menjadi ciri khas masyarakat Banjar yang dimunculkan oleh Anang Ardianysah. Hal ini diperkuat Daud (1997) bahwa memang ditemukan ada keluarga yang hidup anak beranak dalam perahu berkeliling sampai jauh di pedalaman sungai Martapura sambil menjajakan barang dagangannya berupa hasil produksi industri dari daerah asalnya atau barang dagangan lainnya berupa barang-barang kebutuhan pokok.

\section{Permainan}

Alat bermain juga merupakan salah satu artefak budaya yang unik dan bervariasi antara satu budaya masyarakat dan budaya masyarakat yang lain. Setidaknya ada tiga manfaat yang dapat diperoleh dari permainan tradisional. Pertama, permainan tradisional dibuat dari lingkungan sekitar sehingga biaya yang digunakan sedikit dan merangsang kreativitas anak untuk membuatnya. Kedua, pemain yang diperlukan cukup banyak sehingga interaksi antar pemain dapat terbina dengan lebih baik. Ketiga, permainan tradisional mengandung banyak pesan moral tertentu seperti nilai-nilai kebersamaan, kejujuran, tanggung jawab, sikap lapang dada (kalau kalah), dorongan berprestasi, dan taat pada aturan (Nur, 2013).

Masyarakat Banjar memiliki satu permainan yang sangat khas, yaitu balogo. Permainan ini biasanya dimainkan oleh anak-anak. Permainannya 
menggunakan lugu atau logo. Benda ini berbentuk pipih yang terbuat dari tempurung kelapa dengan garis tengah sekitar 5 hingga $7 \mathrm{~cm}$ dan tebal sekitar 1 hingga $2 \mathrm{~cm}$. Selain itu, logo juga dapat dibuat dari hasil lelehan plastik pipa yang disatukan dalam sebuah cetakan. Logo memiliki bentuk yang beragam, misalnya bentuk segi tiga, layang-layang, daun, atau bundar.

Cara memainkannya dapat dilakukan satu lawan satu atau tim. Logo diletakkan secara berderet dengan jarak tertentu. Aturan permainannya ialah pemain berusaha merobohkan logo lawan tersebut dengan meluncurkan logo miliknya. Alat untuk meluncurkan ialah panapak, yaitu stik atau alat pemukul yang panjangnya sekitar $40 \mathrm{~cm}$ dengan lebar $2 \mathrm{~cm}$. Pemenangnya ialah tim atau pemain yang paling banyak merobohkan $\log o$ musuh. Lirik lagu Anang Ardiansyah yang menggambarkan hal ini dapat diamati pada teks berikut ini.

Balogo di tangah jalan
Malancar laju babanaran
Jangan landau urang dituju
Nang lalu lalang taganggu
Gursiah takana busu
Di buang sidin ka banyu

Balogo di tangah jalan Jangan landau urang dituju Nang lalu lalang taganggu Di buang sidin ka banyu
(Balogo di tengah jalan)

(Meluncur sangat cepat)

(Jangan kaki orang yang dijadikan sasaran)

(Yang lalu lalang terganggu)

(Jangan sampai kena saudara)

(Beliau buang ke air)

Anang Ardiansyah menceritakan bagaimana permainan balogo dimainkan oleh anak muda Banjar. Berdasarkan lirik lagu yang ditulisnya biasanya permainan ini dimainkan di tengah jalan. Akibatnya, banyak orang yang lewat di jalan itu merasa terganggu. Anang Ardiansyah mengingatkan para pemain permainan ini agar ketika meluncurkan logo, mereka hanya mengarahkan pada logo milik lawan bukan kaki orang lain. Akibat yang mungkin bisa terjadi bila hal ini dilakukan ialah $\log o$ milik mereka akan diambil dan dibuang ke air. Bila peristiwa ini terjadi, pemiliknya tidak mungkin lagi mengambilnya karena logo milik mereka akan larut terbawa arus air dan hilang.

Lagu ini sangat kental mengandung nilai budaya masyarakat Banjar, khususnya pada aspek permainan. Anang Ardiansyah menampilkan permainan balogo dalam lagunya untuk mempromosikannya kepada generasi muda lebih akrab dengan permainan tradisional. Dia menggambarkan bagaimana serunya balogo ketika dimainkan. Permainan balogo saat ini sangat jarang terlihat dimainkan generasi muda akibat arus teknologi dan budaya asing yang sangat kuat mempengaruhi masyarakat. Melalui lagu ini, Anang Ardiansyah mengharapkan permainan ini tidak punah dan kalah bersaing dengan permainan saat ini, seperti video game, gadget, dan sebagainya.

\section{SIMPULAN}

Penelitian ini menemukan tiga nilai budaya Banjar. Berdasarkan data-data yang dikumpulkan nilai budaya yang dimaksud, yaitu pernikahan, mata pencaharian, dan permainan. Nilai budaya pernikahan yang ditampilkan dalam lagu Anang Ardiansyah ada dua, yaitu jodoh dalam pandangan masyarakat dan pernak pernik pernikahan. Jodoh diyakini masyarakat telah ditetapkan oleh Tuhan sehingga para pemuda yang belum menikah selalu dinasehati agar tidak terlalu khawatir secara berlebihan karena jodoh kadang berasal dari orang yang tidak terduga, seperti teman atau tetangga. Pernak pernik pernikahan merupakan bentuk 
budaya yang jelas terlihat secara fisik sehingga keberadaannya perlu terus dipertahankan secara berkelanjutan. Nilai budaya berupa mata pencaharian dalam lagu ini berisi tentang bagaimana kegigihan masyarakat dalam mencari nafkah. Mata pencaharian masyarakat Banjar umumnya berada di sektor perdagangan. Sebagian masyarakat menjual barang dagangannya ke daerah lain. Nilai budaya yang berbentuk permainan menonjolkan tentang permainan balogo. Tahap dan suasana permainan ini digambarkan sekilas oleh Anang Ardiansyah melalui lagu ciptaannya.

Lagu daerah merupakan media yang cukup berpengaruh untuk menanamkan nilai-nilai budaya kepada masyarakat. Lagu yang disukai akan diputar secara terus-menerus oleh penikmatnya. Selain itu, lagu itu umumnya sering ditampilkan pada acara-acara yang melibatkan masa yang banyak, seperti pernikahan atau peringatan hari-hari besar. Penanaman nilai-nilai pernikahan, mata pencaharian, dan permainan dalam lagu-lagu ciptaan Anang Ardiansyah mengandung nilai yang positif dan layak untuk dipertahankan. Wujud apresiasi yang dapat dilakukan ialah dengan memberikan penghargaan kepada para pencipta lagu daerah Banjar. Selain itu, promosi juga menjadi cara yang sangat efektif untuk membuat lagu-lagu ini terus bertahan, seperti pemutaran pada acaraacara resmi pemerintahan atau perayaan yang dilakukan oleh masyarakat. 


\section{DAFTAR PUSTAKA}

Azhar, I. N. (2009). Karakter masyarakat Madura dalam syair-syair lagu daerah Madura. Atavisme, 12(2), (online), (http://atavisme.web.id/ index.php/atavisme/article/view/171), diakses 8 November 2016.

Daud, A. (1997). Islam dan Masyarakat Banjar: Deskripsi dan Analisa Kebudayaan Banjar. Jakarta: PT Raja Grafindo Persada.

Hoed, B. H. (2011). Semiotik dan Dinamika Sosial Budaya. Jakarta: Komunitas Bambu.

Kim, J. H. (2014). Musical acculturation through primary school activities during japanese colonial rule of korea (1910-1945). British Journal of Music Education, 31(3), 265-280. (online), (doi:http://dx.doi.org/ 10.1017/S0265051714000254), diakses 12 November 2016.

Koentjaraningrat. (1990). Pengantar Ilmu Antropologi. Jakarta: Gramedia.

Mannion, C. M., \& Sanatullova-Allison, E. (2012). Applying the theory of linguistic relativity to music - an initial exploration. International Journal of Arts \& Sciences, 5(3), 455-475. (online), (http://search.proquest.com/ docview/1284080689?accountid=62696), diakses 8 November 2016.

Nur, H. 2013. Membangun Karakter Anak melalui Permainan Anak Tradisional. Jurnal Pendidikan Karakter, 3(1), 87-94. (online), (http://journal.uny.ac.id/ index.php/jpka/ article/download/1290/1074), diakses 22 November 2016.

Otchere, E. D. (2015). Music teaching and the process of enculturation: A cultural dilemma. British Journal of Music Education, 32(3), 291-297. (online), (doi:http://dx.doi.org/ 10.1017/S0265051715000352), diakses 12 November 2016.

Pascale, L. M. (2013). The role of music in education: Forming cultural identity and making cross-cultural connections. Harvard Educational Review, 83(1), 127-134,271. (online), (http://search.proquest.com /docview/ 1326778701 ?accountid=62696), diakses 8 November 2016.

Setiawan, I. (2012). Kepunahan lagu daerah Lir-ilir di era globalisasi. APRON Jurnal Pemikiran Seni Pertunjukan, 1(I), (online), (http://ejournal.unesa.ac.id/ index.php/apron/article/ view/2878), diakses 8 November 2016.

Stokes, J. (2007). How to do Media and Cultural Studies. Yogyakarta: PT Bentang Pustaka. 